Article

\title{
Seed-induced synthesis of small-crystal TS-1 using ammonia as alkali source
}

\author{
Teng Xue, Huaping Liu, Yimeng Wang, Haihong Wu*, Peng Wu, Mingyuan He \\ Shanghai Key Laboratory of Green Chemistry and Chemical Processes, School of Chemistry and Molecular Engineering, East China Normal University, \\ Shanghai 200062, China
}

A R T I C L E I N F 0

Article history:

Received 9 June 2015

Accepted 14 July 2015

Published 20 November 2015

Keywords:

Small crystal

TS-1 molecular sieve

Seed-induced synthesis

Ammonia

Catalytic oxidation

Cyclohexanone ammoximation

\begin{abstract}
A B S T R A C T
Small-crystal TS-1 was synthesized via a seed-induced approach using ammonia as the alkali source and tetrapropylammonium bromide as an auxiliary structure-directing agent. The TS- 1 samples were characterized using X-ray diffraction, $\mathrm{N}_{2}$ adsorption-desorption, Fourier-transform infrared spectroscopy, inductively coupled plasma atomic emission spectroscopy, scanning electron microscopy, and ultraviolet-visible spectroscopy. The use of the colloidal seed reduced the crystal size, and an appropriate amount of silicalite- 1 seed assisted Ti incorporation into the TS- 1 framework. This method reduces the cost of TS- 1 synthesis because a significantly smaller amount of tetrapropylammonium hydroxide is used. The catalytic performance of the synthesized small-crystal TS- 1 samples in cyclohexanone ammoximation was better than that of bulk TS- 1 as a result of improved diffusion and a larger number of active tetrahedral Ti centers.
\end{abstract}

(C) 2015, Dalian Institute of Chemical Physics, Chinese Academy of Sciences. Published by Elsevier B.V. All rights reserved.

\section{Introduction}

TS-1 molecular sieves, which have the MFI topology, have attracted widespread attention because of their shape selectivities and excellent catalytic oxidation performance [1-5]. TS-1 molecular sieves were first developed by EniChem Company in 1983 [6]. In the reported method, a large amount of tetrapropylammonium hydroxide (TPAOH, TPAOH $/ \mathrm{SiO}_{2}=0.4-1.0$ ) was used as a structure-directing agent (SDA), therefore the synthesized TS-1 was expensive [6]. Cheap and environmentally friendly methods for active TS-1 synthesis need to be developed.

Tetrapropylammonium bromide (TPABr) is cheaper and more easily obtained than TPAOH. Müller et al. [7] used TPABr to synthesize TS-1 using ammonia as the alkali source. Howev- er, the crystal size of the obtained zeolite was often greater than $10 \mu \mathrm{m}$, much larger than that typical of TS- 1 synthesized using TPAOH as the SDA. Amines have also been used as alkali sources when using TPABr as the SDA, but micron-scale crystals were obtained [8-11], resulting in poor catalytic performance as a result of severely limited diffusion. Zeolites with small crystallite sizes show enhanced catalytic activities because of increased mass transport and a reduction in coke formation; such zeolites are therefore important [12-14].

The crystal size can be decreased by promoting nucleation to provide larger numbers of crystal nuclei. Seed addition to zeolite synthesis systems can promote nucleation, reduce the induction time, and enhance the crystallization rate, and therefore reduce the product crystal size [15]. TS-1 crystals or TS-1 precursors are usually used as the seeds for the synthesis of

\footnotetext{
* Corresponding author. Tel/Fax: +86-21-62238510; E-mail: hhwu@chem.ecnu.edu.cn This work was supported by the National Natural Science Foundation of China (21403070 and 21373088), Innovation Program of Shanghai Municipal Education Commission (13zz038), Key Project of the Shanghai Committee of Science and Technology (12JC1403600), National Key Technology R\&D Program (2012BAE05B02), and Shanghai Leading Academic Discipline Project (B409).
} DOI: 10.1016/S1872-2067(15)60955-X | http://www.sciencedirect.com/science/journal/18722067 | Chin. J. Catal., Vol. 36, No. 11, November 2015 
small-crystal TS-1 molecular sieves. Deng et al. [16] reported a two-step or multistep hydrolysis method for the synthesis of TS-1 with a controllable morphology and particle size. In this method, a high $\mathrm{TPAOH} / \mathrm{SiO}_{2}$ ratio led to fast hydrolysis and condensation of tetraethyl orthosilicate (TEOS) in the first step, which helped the formation of sufficient nuclei. When the remaining TEOS was added, the nuclei formed in the first step served as seeds and further catalyzed the nucleation and crystallization of TS-1. The amount of TPAOH used as the SDA is significantly decreased by using this two-step or multistep hydrolysis method. However, this process is tedious because it involves the multistep hydrolysis of TEOS and alcohol removal by evaporation. Furthermore, the crystal size increased from $\sim 400$ to $\sim 900 \mathrm{~nm}$ when the ratio of $\mathrm{TPAOH} / \mathrm{SiO}_{2}$ was decreased from 0.12 to 0.065 . Xia et al. [17] synthesized TS-1 molecular sieves using tetraethylammonium chloride (TEACl) and tetrabutylammonium chloride (TBACl) as a mixed SDA, amines or ammonia as alkali sources, and $\mathrm{TiCl}_{3}$ as a Ti source. The addition of TS- 1 as the seed to the synthesis mixture reduced the crystal size to $\sim 400-600 \mathrm{~nm}$. In addition to the use of TS-1 seeds (1-20 wt\%), a large amount of organic SDA ((TEACl + $\mathrm{TBACl}) / \mathrm{SiO}_{2}=0.202$ ) was used. Zhang et al. [18] prepared TS-1 using active TS-1 as seeds, inexpensive hexamethyleneimine as the SDA, and fumed silica as the Si source. The crystal size of the obtained TS- 1 was about $10 \mu \mathrm{m}$, and the zeolite gave a poor performance in the catalytic epoxidation of $n$-hexene. Zuo et al. [19] reported the synthesis of small-crystal TS-1 using TS-1 mother liquid as the seed, with colloidal silica and $\mathrm{TiCl}_{4}$ as the Si source and Ti source, respectively. TPABr was used as a template, with aqueous ethylamine as the base. The TS- 1 sample had small crystals, of size about $600 \mathrm{~nm} \times 400 \mathrm{~nm} \times 250 \mathrm{~nm}$, and gave a good catalytic performance in the epoxidation of propylene and the hydroxylation of phenol. In addition to TS-1 mother liquid as the seed, a certain amount of $\mathrm{TPABr}$ ( $\mathrm{TPABr} / \mathrm{SiO}_{2}=0.15$ ) was used as an SDA. In a previous study [20], we used colloidal silicalite- 1 as the seed for the synthesis of hierarchical nanocrystalline TS- 1 . The obtained TS- 1 had a crystal size of about 300-500 nm, and a large amount of mesopores were formed by particle-particle aggregation; the total molar ratio of $\mathrm{TPAOH} / \mathrm{SiO}_{2}$ was reduced to 0.12 . Huang et al. [21] synthesized TS- 1 at a low $\mathrm{TPAOH} / \mathrm{SiO}_{2}$ ratio, 0.05 ; a TS-1 precursor sol of molar composition $\mathrm{SiO}_{2}: 0.033 \mathrm{TiO}_{2}$ : $0.25 \mathrm{TPAOH}: 20 \mathrm{H}_{2} \mathrm{O}$ was used as the seed, and simultaneously provided TPAOH as the SDA. The synthesized TS- 1 had a uniform crystal size of $\sim 0.3 \mu \mathrm{m}$, very high crystallinity, and a large content of framework Ti, resulting in high activity in cyclohexanone ammoximation. However, a large amount of extra $n$-butylamine $(n$-BA/SiO $2=0.6)$ was needed to increase the alkalinity and to promote TS-1 nucleation. Furthermore, the hydrothermal syntheses had to be performed using a temperature-programmed process. Wang et al. [22] used pre-prepared TS- 1 as seeds and achieved a reduction in the $\mathrm{TPA}^{+} / \mathrm{SiO}_{2}$ ratio to 0.03 , but the obtained zeolite sizes were in the micron range. Zhang et al. [23] reported a novel solid-state transformation strategy for the low-cost synthesis of nano-sized TS-1, using a TS- 1 precursor sol. The $\mathrm{TPAOH} / \mathrm{SiO}_{2}$ molar ratio was reduced to 0.05 . The obtained TS- 1 particles were of size $200-400 \mathrm{~nm}$ and consisted of $50 \mathrm{~nm}$ primary crystallites. They gave an excellent catalytic oxidation performance in the epoxidation of 1-hexene. This method is promising because of the low dose of TPAOH and the use of inorganic silica powder as the silica source. It also enhances efficiency of starting raw material use and avoids filtration and washing steps.

These previous studies suggest that the use of a colloidal TS-1 precursor as seeds is effective for the low-cost synthesis of TS-1, in both hydrothermal and solid-state transformation routes. However, care must be taken when synthesizing the TS-1 precursor to ensure appropriate coordination states of the Ti species; tetrabutyl titanate (TBOT) hydrolysis must be performed at low temperatures (usually $0{ }^{\circ} \mathrm{C}$ ) and then the alcohols formed by TEOS and TBOT hydrolysis need to be removed at higher temperatures (usually $60-80{ }^{\circ} \mathrm{C}$ ) $[21,23]$. These tedious procedures can be avoided by using a pure-silica silicalite-1 precursor. Colloidal silicalite- 1 has been widely used as the seed for the synthesis of ZSM-5, which has the same MFI structure as TS-1 [24-30].

In this study, we investigated the synthesis of small-crystal TS-1 zeolites using pure-silica silicalite- 1 as the seed, ammonia as the alkali source, and TPABr as an auxiliary SDA. The catalytic oxidation performance of TS- 1 depends closely on both the crystal size and the coordination states of the Ti species [31]. The effects of using various amounts of silicalite- 1 on the physicochemical and catalytic properties of the obtained TS-1 samples were investigated. The epoxidation of 1-hexene and cyclohexanone ammoximation were used as probe reactions for evaluation of the catalytic performance.

\section{Experimental}

\subsection{Synthesis of small-crystal TS-1}

The colloidal silicalite-1 seed was prepared according to the literature method, with TEOS (Sinopharm Chemical Reagent Co., Ltd.) as the Si source and TPAOH (25 wt\% aqueous solution, Sinopharm) as the SDA, using $\mathrm{SiO}_{2}: 0.35 \mathrm{TPAOH}: 20 \mathrm{H}_{2} \mathrm{O}$ : $4 \mathrm{EtOH}$ (produced by hydrolysis of TEOS) molar ratios [29]. In a typical synthesis, TEOS (21.2 g) and TPAOH (35.0 g) were mixed under stirring at room temperature. After TEOS hydrolysis, $\mathrm{H}_{2} \mathrm{O}$ (8.2 g) was added and the mixture was treated hydrothermally in a Teflon-lined stainless-steel autoclave at $80^{\circ} \mathrm{C}$ for $72 \mathrm{~h}$. The obtained colloidal silicalite- 1 was cooled to room temperature and used in the subsequent synthesis without any treatment. The amounts of $\mathrm{SiO}_{2}$ and $\mathrm{TPAOH}$ in the colloidal silicalite- 1 seed were $9.35 \mathrm{wt} \%$ and $11.07 \mathrm{wt} \%$, respectively.

In the synthesis of small-crystal TS-1, aqueous ammonia (25-28 wt\% ammonia, Sinopharm Chemical Reagent Co., Ltd.) was used to hydrolyze TBOT ( $\geq 98.0 \mathrm{wt} \%$, Sinopharm) and TEOS, which were used as the Ti and $\mathrm{Si}$ sources, respectively. $\mathrm{H}_{2} \mathrm{O}_{2}$ was used to disperse the TBOT and to control the hydrolysis. Aqueous ammonia was dissolved in deionized water, and TBOT, $\mathrm{H}_{2} \mathrm{O}_{2}$, and TEOS were successively added dropwise under stirring. Full hydrolysis of TBOT and TEOS gave a mixture of molar composition $\mathrm{SiO}_{2}: 0.5 \mathrm{NH}_{3} \cdot \mathrm{H}_{2} \mathrm{O}: 0.025 \mathrm{TiO}_{2}: 4 \mathrm{EtOH}$ : $0.1 \mathrm{Bu}{ }^{t} \mathrm{OH}: \mathrm{H}_{2} \mathrm{O}_{2}: 20 \mathrm{H}_{2} \mathrm{O}$ (EtOH and $\mathrm{Bu}^{t} \mathrm{OH}$ were produced by 
hydrolysis of TEOS and TBOT, respectively). The mixture was heated at $60{ }^{\circ} \mathrm{C}$ for $6 \mathrm{~h}$ in a water bath; a mixture of $\mathrm{pH} \sim 7$ was obtained. A small amount of TPABr ( $99 \mathrm{wt} \%$, Sinopharm), used as an auxiliary organic template, and the colloidal silicalite-1 seed were then added to the mixture. The final molar composition for the syntheses was $\mathrm{SiO}_{2}: 0.025 \mathrm{TiO}_{2}: x \mathrm{TPABr}: y \mathrm{TPAOH}$ (cs- $c$ wt $\%$ ): $20 \mathrm{H}_{2} \mathrm{O}$ (see Table 1 for $x$ and $y$; cs- $c$ wt $\%$ denotes that TPAOH was introduced from the colloidal silicalite- 1 seed and the amount of $\mathrm{SiO}_{2}$ in the colloidal seed represented $c \mathrm{wt} \%$ of the total $\mathrm{SiO}_{2}$ in the batch). The obtained gel was transferred to a Teflon-lined stainless-steel autoclave and heated at $175^{\circ} \mathrm{C}$ for $3 \mathrm{~d}$. When crystallization was complete, the autoclave was quenched and cooled to room temperature. The solid product was separated from the mother liquor by filtration. The product was washed several times with deionized water, dried at $100{ }^{\circ} \mathrm{C}$ overnight, and calcined at $550{ }^{\circ} \mathrm{C}$ for $6 \mathrm{~h}$ to remove the organic template. For comparison, a control experiment was performed using a molar composition of $\mathrm{SiO}_{2}: 0.025 \mathrm{TiO}_{2}$ : 0.033TPABr:0.07TPAOH: $20 \mathrm{H}_{2} \mathrm{O}$, by replacing the colloidal seed with TPAOH, with the other components unchanged.

\subsection{Characterization}

Powder X-ray diffraction (XRD) patterns of the samples were recorded using a Rigaku X-ray diffractometer, with Ni-filtered $\mathrm{Cu} K_{\alpha}$ radiation $(\lambda=0.15418 \mathrm{~nm})$ at $30 \mathrm{kV}$ and 30 $\mathrm{mA}$, and scanning in the $2 \theta$ range $5^{\circ}-35^{\circ}$ at an angular rate of $5^{\circ} / \mathrm{min}$. The relative crystallinities of the products were determined from the peak areas in the $2 \theta$ range $22.5^{\circ}-25^{\circ}$ using the sample with the highest crystallinity as the reference. Scanning electron microscopy (SEM) images were obtained using a field-emission scanning electron microscope (Hitachi S-4800), operated at an accelerating voltage of $3 \mathrm{kV} . \mathrm{N}_{2}$ adsorption-desorption measurements were performed at $-196{ }^{\circ} \mathrm{C}$ using a BELsorp-MAX volumetric adsorption analyzer. The samples were out-gassed at $300{ }^{\circ} \mathrm{C}$ for $6 \mathrm{~h}$ before the adsorption measurements. The specific surface areas were determined by the Brunauer-Emmett-Teller (BET) method using data in the $p / p_{0}$ range $0.01-0.2$. The $t$-plot method was used to discriminate between micro- and meso-porosity. Fourier-transform infrared (FT-IR) spectroscopy was performed (Nicolet NEXUS 670 FT-IR spectrometer) in the range $400-4000 \mathrm{~cm}^{-1}$ using $\mathrm{KBr}$ disks. The bulk $\mathrm{SiO}_{2} / \mathrm{TiO}_{2}$ ratio of the small-crystal TS-1 was determined using inductively coupled plasma atomic emission spectroscopy (ICP-AES, Thermo IRIS Intrepid II XSP). Ultraviolet-visible (UV-vis) spectra were obtained using a Shimadzu UV-2700 spectrometer equipped with an integrating sphere, using $\mathrm{BaSO}_{4}$ as a reference.

\subsection{Catalytic tests}

The epoxidation of $n$-hexene and ammoximation of cyclohexanone were used as probe reactions to evaluate the catalytic performance of the obtained TS- 1 molecular sieves. $n$-Hexene epoxidation was performed in a $50-\mathrm{mL}$ glass reactor equipped with a reflux condenser and a magnetic stirrer. In a typical reaction, catalyst (50 mg), solvent $(10 \mathrm{~mL}), n$-hexene $(10 \mathrm{mmol})$, and $30 \mathrm{wt} \% \mathrm{H}_{2} \mathrm{O}_{2}$ aqueous solution ( $10 \mathrm{mmol}$ ) were introduced into the reactor and the mixture was heated at $80{ }^{\circ} \mathrm{C}$ under constant stirring in a water bath for $2 \mathrm{~h}$. The liquid samples were analyzed using a gas chromatograph (Shimadzu GC-2014) equipped with a $30 \mathrm{~m}$ DB-wax capillary column and a flame ionization detector. Cyclohexane was used as the internal standard for the determination of the $n$-hexene conversion and epoxide selectivity. Cyclohexanone ammoximation was performed at $76{ }^{\circ} \mathrm{C}$ at atmospheric pressure in a three-necked flask. The obtained TS-1 (150 mg) was used as the catalyst, 30 wt $\% \mathrm{H}_{2} \mathrm{O}_{2}$ aqueous solution was used as the oxidant, and an equimolar mixture of $\mathrm{H}_{2} \mathrm{O}$ and tert-butanol was used as the solvent. The molar composition of the reaction batch was solvent: $\mathrm{NH}_{3} \cdot \mathrm{H}_{2} \mathrm{O}: \mathrm{H}_{2} \mathrm{O}_{2}$ :cyclohexanone $=4.0: 1.7: 1.1: 1.0$; the catalyst dose was $15.0 \mathrm{~g}$ per mole of cyclohexanone. The products were analyzed using a gas chromatograph (Shimadzu GC-2014) equipped with a flame ionization detector and a J\&W $30 \mathrm{~m} \times$ $320 \mu \mathrm{m} \times 0.25 \mu \mathrm{m}$ capillary column.

\section{Results and discussion}

\subsection{Characterization}

Fig. 1 shows the XRD patterns of the TS- 1 samples prepared using different amounts of colloidal silicalite- 1 as seeds and TPABr as the auxiliary SDA. For comparison, the XRD pattern of the solid product prepared using TPAOH instead of the colloidal silicalite- 1 seed is also included. When a $\mathrm{SiO}_{2}: 0.025 \mathrm{TiO}_{2}$ : 0.033TPABr:0.07TPAOH: $20 \mathrm{H}_{2} \mathrm{O}$ molar composition was used,

Table 1

Synthetic conditions and properties of obtained TS-1 molecular sieves.

\begin{tabular}{|c|c|c|c|c|c|c|c|c|c|c|}
\hline \multirow{2}{*}{ Sample } & \multicolumn{2}{|c|}{ Batch composition a } & \multirow{2}{*}{$\begin{array}{l}\text { r.c. }^{\text {b }} \\
(\%)\end{array}$} & \multirow{2}{*}{$\begin{array}{c}\mathrm{SiO}_{2} / \mathrm{TiO}_{2} \\
\text { ratio }^{c}\end{array}$} & \multicolumn{6}{|c|}{ Physical properties } \\
\hline & $x$ & $y$ & & & $S_{\text {BET }} /\left(\mathrm{m}^{2} / \mathrm{g}\right)$ & $S_{\text {mic }} \mathrm{e} /\left(\mathrm{m}^{2} / \mathrm{g}\right)$ & $S_{\text {ext }} \mathrm{e} /\left(\mathrm{m}^{2} / \mathrm{g}\right)$ & $V_{\mathrm{t}}^{\mathrm{f}} /\left(\mathrm{cm}^{3} / \mathrm{g}\right)$ & $V_{\mathrm{mic}} \mathrm{e} /\left(\mathrm{cm}^{3} / \mathrm{g}\right)$ & $V_{\text {sec }} \mathrm{g} /\left(\mathrm{cm}^{3} / \mathrm{g}\right)$ \\
\hline $\mathrm{a}$ & 0.033 & 0.070 & 100 & 43.1 & 427.7 & 387.7 & 40.0 & 0.20 & 0.17 & 0.03 \\
\hline $\mathrm{b}$ & 0.033 & 0.070 (cs-20\%) & 98 & 42.4 & 447.0 & 361.0 & 86.0 & 0.31 & 0.16 & 0.15 \\
\hline c & 0.033 & 0.053 (cs-15\%) & 99 & 42.8 & 445.7 & 372.6 & 73.1 & 0.27 & 0.17 & 0.10 \\
\hline$\underline{\mathrm{d}}$ & 0.033 & 0.035 (cs-10\%) & 86 & 42.9 & 400.4 & 340.4 & 60.0 & 0.25 & 0.15 & 0.10 \\
\hline
\end{tabular}

${ }^{\mathrm{a}} \mathrm{SiO}_{2}: 0.025 \mathrm{TiO}_{2}: x \mathrm{TPABr}: y \mathrm{TPAOH}: 20 \mathrm{H}_{2} \mathrm{O}$.

${ }^{\mathrm{b}}$ Relative crystallinity using the sample prepared with the molar composition of $\mathrm{SiO}_{2}: 0.025 \mathrm{TiO}: 0.033 \mathrm{TPABr}: 0.07 \mathrm{TPAOH}: 20 \mathrm{H}_{2} \mathrm{O}$ as reference sample.

${ }^{c}$ Determined using ICP-AES.

d Calculated by the BET method using the data points of $p / p_{0}$ in the range of $0.01-0.2$.

e Calculated using the $t$-plot method.

${ }^{\mathrm{f}}$ Calculated by measuring the amount of adsorbed nitrogen at $p / p_{0}=0.99$.

g Secondary pore volume defined as $V_{\text {sec }}=V_{\mathrm{t}}-V_{\text {mic. }}$. 


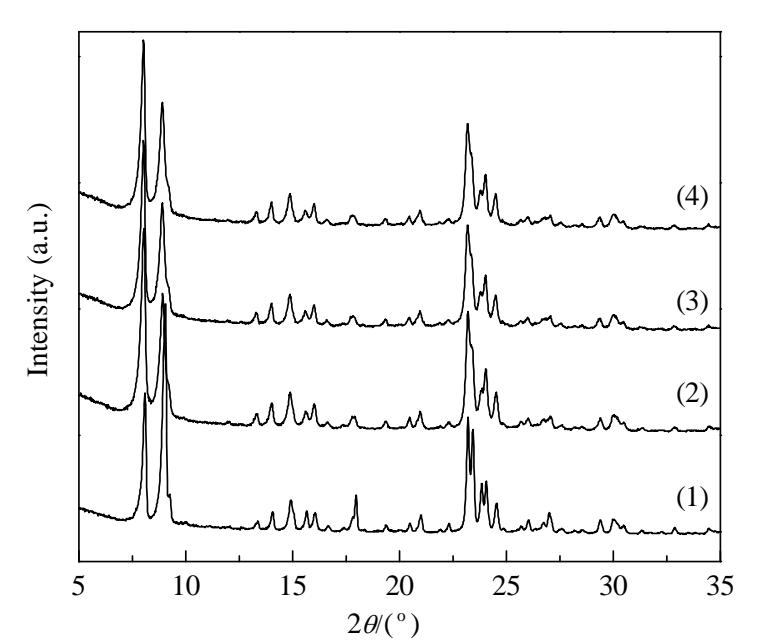

Fig. 1. XRD patterns of the TS- 1 samples prepared using TPAOH as SDA (1) and $20 \mathrm{wt} \%$ (2), $15 \mathrm{wt} \%$ (3), and $10 \mathrm{wt} \%$ (4) of colloidal silicalite-1 as seed.

TS-1 samples with similar crystallinities were obtained using colloidal silicalite-1 (20 wt\%) or TPAOH (Table 1). However, the XRD peaks of the TS- 1 sample prepared directly using TPAOH as the SDA were much sharper and narrower than those of the samples obtained using colloidal silicalite- 1 as the seed. This could result from the crystal sizes. Highly crystalline TS-1 was still obtained when the amount of colloidal silicalite-1 seed was reduced. The crystallinity of TS-1 synthesized using $15 \mathrm{wt} \%$ of colloidal silicalite- 1 seed was similar to that of TS-1 obtained using $20 \mathrm{wt} \%$ of seed (Table 1, samples b and c). When the amount of colloidal seed was further reduced to 10 $w t \%$, the crystallinity of the obtained product decreased slightly (Table 1, sample d). This might be caused by the low alkalinity and/or loss of structure-directing ability of the synthesis system when the amount of colloidal silicalite- 1 seed was reduced. The use of colloidal silicalite- 1 as the seed, ammonia as the alkali source, and TPABr as the auxiliary SDA, enabled highly crystalline TS- 1 to be produced using $\mathrm{TPA}^{+} / \mathrm{SiO}_{2}=0.07$; this is much lower than previously reported values using a TS-1 precursor as the seed $[19,20]$. Another advantage of this process is the use of ammonia, which avoids the use of large amounts of organic amines, as reported by Huang et al. [21].

The SEM images in Fig. 2. show the morphologies of the obtained TS-1 samples. TS- 1 synthesized using a molar composition of $\mathrm{SiO}_{2}: 0.025 \mathrm{TiO}_{2}: 0.033 \mathrm{TPABr}: 0.07 \mathrm{TPAOH}: 20 \mathrm{H}_{2} \mathrm{O}$ had a bulk morphology when TPAOH was used directly (Fig. 2(a)); this is in agreement with its sharper and narrower XRD peaks. The crystal size clearly decreased when colloidal silicalite-1 seed was used. TS-1 consisting of spherical particles of size about $100 \mathrm{~nm}$ was obtained when $20 \mathrm{wt} \%$ of colloidal seed was used (Fig. 2(b)). When the amount of colloidal seed was reduced to $15 \mathrm{wt} \%$, the obtained TS- 1 showed intergrowth, and the primary crystal size increased to about $250 \mathrm{~nm} \times 150 \mathrm{~nm} \times$ $50 \mathrm{~nm}$ (Fig. 2(c)). On further decreasing the amount of colloidal seed to $10 \mathrm{wt} \%$, the primary particle size remained the same, but the morphology was tabular (Fig. 2(d)). Amorphous phases were not observed in the SEM images, although the sample

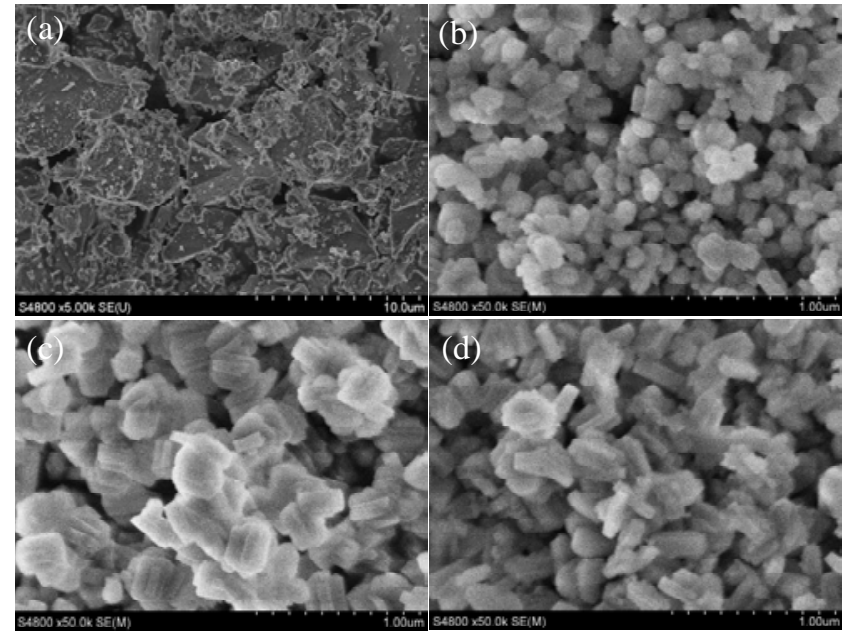

Fig. 2. SEM images of the TS-1 samples prepared using TPAOH as SDA (a) and $20 \mathrm{wt} \%$ (b), $15 \mathrm{wt} \%$ (c), and $10 \mathrm{wt} \%$ (d) of colloidal silicalite-1 as seed.

prepared using $10 \mathrm{wt} \%$ of colloidal silicalite- 1 seed showed the lowest XRD crystallinity. The small-crystal TS-1 prepared by Zuo et al. [19] using TS-1 mother liquid as the seed had a crystal size of about $150 \mathrm{~nm}$, and the particle sizes of the TS-1 samples obtained by Huang at al. [21] using a TS-1 precursor sol as the seed were about $300 \mathrm{~nm}$. The TS-1 samples prepared in this study had much smaller particle sizes, especially when the total amount of TPA ${ }^{+}$was low and the use of an extra organic amine as the alkali source was avoided.

$\mathrm{N}_{2}$ sorption measurements were performed to determine the textural properties of the prepared TS-1 samples; the isotherms are shown in Fig. 3. TS-1 synthesized using a molar composition of $\mathrm{SiO}_{2}: 0.025 \mathrm{TiO}_{2}: 0.033 \mathrm{TPABr}: 0.07 \mathrm{TPAOH}: 20 \mathrm{H}_{2} \mathrm{O}$ showed a typical type I isotherm when TPAOH was used directly, indicating microporous properties. The isotherms of the samples prepared using different amounts of colloidal silicalite- 1 as the seed showed increased $N_{2}$ uptake in the higher

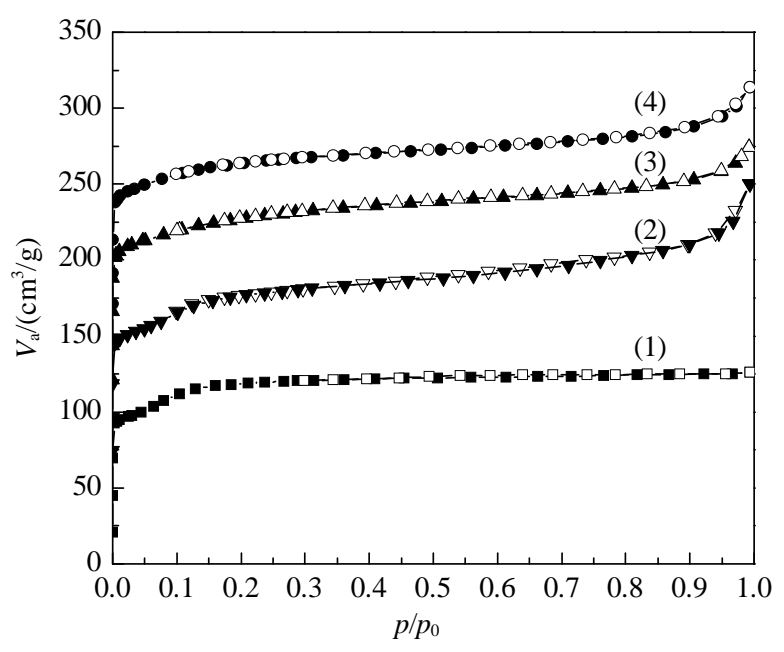

Fig. 3. $\mathrm{N}_{2}$ adsorption-desorption isotherms of TS-1 prepared using TPAOH as SDA (1) and $20 \mathrm{wt} \%$ (2), $15 \mathrm{wt} \%$ (3), and $10 \mathrm{wt} \%$ (4) of colloidal silicalite- 1 as seed. Isotherms for samples (2), (3), and (4) are offset vertically by 50,100 , and $150 \mathrm{~cm}^{3} / \mathrm{g}$, respectively. 
relative pressure range; this can be ascribed to condensation of $\mathrm{N}_{2}$ in the interparticle voids formed by the small crystallites. Correspondingly, the external surface areas $\left(S_{\text {ext }}\right)$ and secondary pore volumes $\left(V_{\text {sec }}\right)$ of the small-crystal TS-1 were larger than those of the bulk material obtained when TPAOH was used directly (Table 1). Furthermore, the larger the amount of colloidal seed used, the higher the pore volume of the synthesized zeolite was. The sample synthesized using $20 \mathrm{wt} \%$ of colloidal seed had $S_{\text {ext }}$ and $V_{\text {sec }}$ values of $86 \mathrm{~m}^{2} / \mathrm{g}$ and 0.15 $\mathrm{cm}^{3} / \mathrm{g}$, respectively, much higher than those of the sample synthesized directly using TPAOH as the SDA. All the samples had BET surface areas $\left(S_{\mathrm{BET}}\right)$ of larger than $400 \mathrm{~m}^{2} / \mathrm{g}$. The sample prepared using $10 \mathrm{wt} \%$ of colloidal seed adsorbed the lowest amount of $\mathrm{N}_{2}$, corresponding to the smallest $S_{\mathrm{BET}}, 400 \mathrm{~m}^{2} / \mathrm{g}$, micropore surface area $\left(S_{\text {mic }}\right), 340 \mathrm{~m}^{2} / \mathrm{g}$, and micropore volume ( $V_{\text {mic }}$ ), $0.15 \mathrm{~cm}^{3} / \mathrm{g}$. The other samples had $S_{\text {mic }}$ values higher than $360 \mathrm{~m}^{2} / \mathrm{g}$ and $V_{\text {mic }}$ values larger than $0.16 \mathrm{~cm}^{3} / \mathrm{g}$. These results are in accordance with the XRD results.

FT-IR spectra of the synthesized TS- 1 samples are shown in Fig. 4. The absorption peaks at 1100,800 , and $450 \mathrm{~cm}^{-1}$ are assigned to internal vibrations of $(\mathrm{Si}, \mathrm{Ti}) \mathrm{O}_{4}$; these are also present in materials such as amorphous $\mathrm{SiO}_{2}$, quartz, and christobalite. The absorption peaks at 1230 and $550 \mathrm{~cm}^{-1}$ are ascribed to the double-ring tetrahedral vibrations and asymmetric stretching of $\mathrm{SiO}_{4}$ and $\mathrm{TiO}_{4}$ tetrahedra in the zeolite framework, respectively. The intensity ratio of the peaks at 550 and 450 $\mathrm{cm}^{-1}\left(I_{550} / I_{450}\right)$ is generally used to evaluate the crystallinity of a zeolite with the MFI topology, and is called the IR crystallinity $[32,33]$. The $I_{550} / I_{450}$ ratios for the samples synthesized using 10,15 , and $20 \mathrm{wt} \%$ of colloidal silicalite- 1 seed were $0.61,0.72$, and 0.73 , respectively; that for the bulk sample prepared directly using $\mathrm{TPAOH}$ as the SDA was 0.73 . It was reported that $I_{550} / I_{450}$ for pure-silica silicalite- 1 with a particle size of $2-4 \mu \mathrm{m}$ was 0.8 , and the value for directly synthesized $\mathrm{NH}_{4}-\mathrm{ZSM}-5$ was in the range 0.69-0.72 $[29,34,35]$. This demonstrates that the small-crystal TS- 1 synthesized in this study using colloidal silicalite- 1 seed had high crystallinity. The $I_{550} / I_{450}$ ratio for the sample prepared using $10 \mathrm{wt} \%$ of colloidal silicalite- 1 seed was

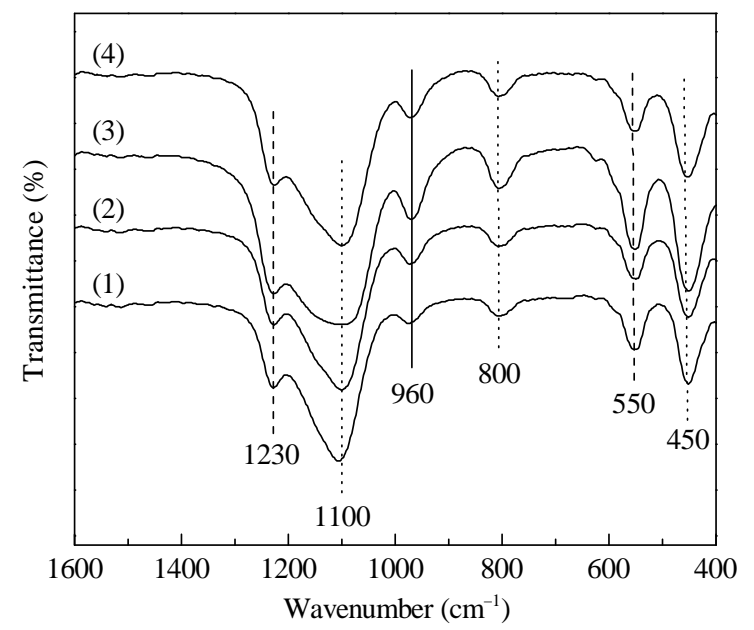

Fig. 4. FT-IR spectra of TS-1 molecular sieves prepared using TPAOH as SDA (1) and $20 \mathrm{wt} \%$ (2), $15 \mathrm{wt} \%$ (3), and $10 \mathrm{wt} \%$ (4) of colloidal silicalite- 1 as seed. lower than those of the others, showing that the sample had lower crystallinity; this is consistent with the XRD results. All the prepared samples showed a clear absorption band at $\sim 960$ $\mathrm{cm}^{-1}$, which is usually assigned to the stretching vibration of $\left[\mathrm{SiO}_{4}\right]$ units strongly influenced by Ti ions in neighboring coordination sites. This absorption, which is not observed for pure silicate molecular sieves, is a strong indicator of Ti incorporation into the TS-1 framework [36]. The intensity ratio for the bands at $\sim 960$ and $800 \mathrm{~cm}^{-1}, I_{960} / I_{800}$, is proportional to the content of framework $\mathrm{Ti}$ and is usually used to evaluate the level of Ti incorporated into the framework [37]. The $I_{960} / I_{800}$ ratio of the bulk TS-1 sample prepared directly using TPAOH as the SDA was much lower than those of the small-crystal TS-1 samples prepared using colloidal silicalite- 1 as the seed, suggesting that use of a colloidal seed facilitated Ti incorporation into the TS-1 framework.

The bulk $\mathrm{SiO}_{2} / \mathrm{TiO}_{2}$ molar ratios of the obtained TS- 1 samples were $\sim 43$, slightly higher than the batch $\mathrm{SiO}_{2} / \mathrm{TiO}_{2}$ ratio (Table 1). This could be caused by low incorporation of Ti species. Zhao et al. [38] reported that only $90 \%$ of the Ti species in the synthesis gel were found in the solid product. The Ti coordination states in the TS-1 samples were examined using diffuse-reflectance UV-vis spectrometry, which is sensitive to the electronic states of Ti species [32,39]; the spectra are shown in Fig. 5. A strong absorption band centered at $210 \mathrm{~nm}$ was observed for all the obtained samples, indicating that most $\mathrm{Ti}$ atoms were tetrahedrally coordinated. A weak absorption at about $270 \mathrm{~nm}$ was also observed for the samples prepared using colloidal silicalite- 1 as the seed. This absorption arises from charge transfer in isolated [HOTiO 3 ] units, i.e., tetrahedrally coordinated Ti species with less attachment to the silica support through Ti-O-Si linkages [40]. An absorption band at $320 \mathrm{~nm}$, which is ascribed to non-framework Ti species [31], was observed in the spectra, particularly for the bulk sample prepared using TPAOH as the SDA and the sample synthesized using $20 \mathrm{wt} \%$ of colloidal seed. If too much colloidal silicate- 1 is used, an increased amount of alcohol is introduced. This might be unfavorable to Ti incorporation. This means that use of an

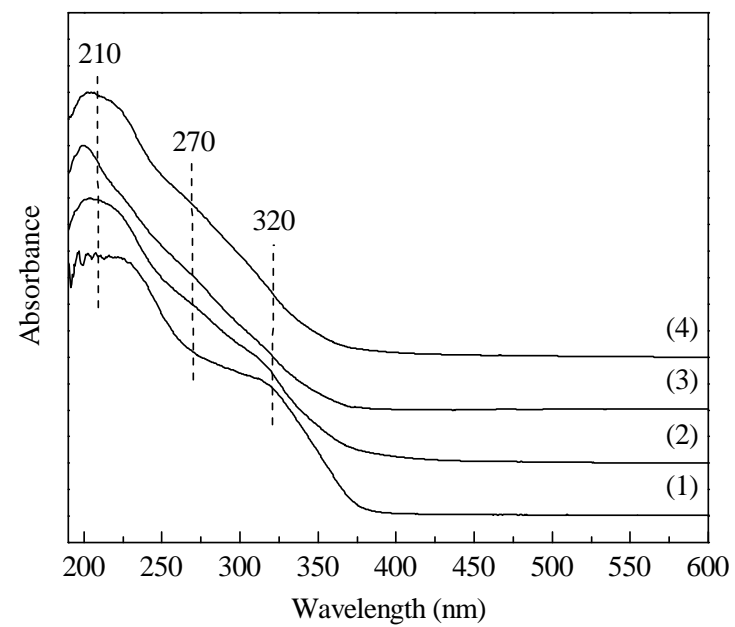

Fig. 5. UV-vis spectra of the TS- 1 samples prepared using TPAOH as SDA (1) and $20 \mathrm{wt} \%$ (2), $15 \mathrm{wt} \%$ (3), and $10 \mathrm{wt} \%$ (4) of colloidal silicalite- 1 as seed. 
Table 2

Catalytic performance of the obtained TS- 1 molecular sieves.

\begin{tabular}{|c|c|c|c|c|}
\hline \multirow[b]{2}{*}{ Sample a } & \multicolumn{2}{|c|}{ 1-Hexene epoxidation } & \multicolumn{2}{|c|}{ Cyclohexanone ammoximation } \\
\hline & $\begin{array}{c}\text { Conversion } \\
(\%)\end{array}$ & $\begin{array}{c}\text { Selectivity } \\
(\%)\end{array}$ & $\begin{array}{c}\text { Conversion } \\
(\%)\end{array}$ & $\begin{array}{c}\text { Selectivity } \\
(\%)\end{array}$ \\
\hline $\mathrm{a}$ & 10.8 & 99.1 & 16.6 & 99.5 \\
\hline $\mathrm{b}$ & 13.9 & 99.3 & 91.5 & 99.5 \\
\hline c & 10.7 & 99.1 & 92.8 & 99.9 \\
\hline $\mathrm{d}$ & 12.3 & 99.0 & 93.9 & 90.1 \\
\hline
\end{tabular}

${ }^{a}$ See Table 1 for the synthetic conditions.

appropriate amount of the colloidal seed could facilitate Ti incorporation into the zeolitic framework.

\subsection{Catalytic results}

The catalytic performance of the TS-1 samples was investigated in the epoxidation of $n$-hexene and ammoximation of cyclohexanone. 1-Hexene conversions in selective oxidation by $\mathrm{H}_{2} \mathrm{O}_{2}$ catalyzed by the synthesized TS- 1 samples were in the range $10 \%-14 \%$, irrespective of the crystal size (Table 2). This can be ascribed to the small 1-hexene molecules having easy access to the active Ti sites in the catalysts. The epoxidation of $n$-hexene is not limited by intracrystalline diffusion and is therefore not influenced by the crystal size. When cyclohexanone ammoximation was used as the probe reaction, the conversion of cyclohexanone clearly differed depending on the crystal size. Only $16 \%$ cyclohexanone conversion was achieved when the catalyst was bulk TS-1 obtained directly using TPAOH as the SDA. When the small-crystal TS-1 samples prepared using various amounts of colloidal silicalite- 1 as the seed were used as the catalyst, the cyclohexanone conversion increased to higher than $90 \%$ (Table 2). Cyclohexanone is relatively large and the reaction is diffusion controlled. The use of small-crystal TS-1 facilitated the diffusion of bulky molecules to and from the active Ti centers. Furthermore, the small crystals have larger numbers of active tetrahedral Ti centers, which might also lead to higher conversion than that achieved using the bulk material. However, it should be pointed out that the 1-hexene conversions in selective oxidation by $\mathrm{H}_{2} \mathrm{O}_{2}$ catalyzed by the small-crystal TS-1 samples synthesized here were slightly lower than that reported previously [20]. The zeolite catalytic activity is closely related not only to the type of reaction, but also to the zeolite crystallinity, the coordination state, and location of the active centers $[16,20,31,41]$. A comprehensive investigation of the catalytic activities of these TS- 1 samples is still needed.

\section{Conclusions}

Small-crystal TS-1 was synthesized using pure-silica colloidal silicalite- 1 as the seed, a small amount of TPABr as an auxiliary SDA, and ammonia as the alkali source. The use of a colloidal seed reduced the total $\mathrm{TPA}^{+} / \mathrm{SiO}_{2}$ ratio needed to 0.07 . The small-crystal TS-1 samples synthesized in this study had high crystallinities, and the crystal sizes were in the range 100-300 $\mathrm{nm}$. An appropriate amount of the colloidal seed facil- itated Ti incorporation into the zeolitic framework. The catalytic performance of the small-crystal TS-1 samples in cyclohexanone ammoximation was better than that of bulk TS-1 prepared directly using TPAOH as the SDA; this was the result of improved diffusion and larger numbers of active tetrahedral Ti centers.

\section{References}

[1] Maspero F, Romano U.J Catal, 1994, 146: 476

[2] Martens J A, Buskens P, Jacobs P A, van der Pol A, van Hooff J H C, Ferrini C, Kouwenhoven H W, Kooyman P J, van Bekkum H. Appl Catal A, 1993, 99: 71

[3] Clerici M G. Appl Catal, 1991, 68: 249

[4] Thangaraj A, Sivasanker S, Ratnasamy P. J Catal, 1991, 131: 394

[5] Clerici M G, Bellussi G, Romano U.J Catal, 1991, 129: 159

[6] Taramasso M, Perego G, Notari B. US Patent 4410501. 1983

[7] Müller U, Steck W. Stud Surf Sci Catal, 1994, 84: 203

[8] Wang X S, Guo X W. Catal Today, 1999, 51: 177

[9] Li G, Guo X W, Wang X S, Zhao Q, Bao X H, Han X W, Lin L W. Appl Catal A, 1999, 185: 11

[10] Shibata M, Gérard J, Gabelica Z. Stud Surf Sci Catal, 1997, 105: 245

[11] Tuel A. Zeolites, 1996, 16: 108

[12] Yang G J, Wei Y X, Xu S T, Chen J R, Li J Z, Liu Z M, Yu J H, Xu R R.J Phys Chem C, 2013, 117: 8214

[13] Sun Q M, Ma Y H, Wang N, Li X, Xi D Y, Xu J, Deng F, Yoon K B, Oleynikov P, Terasaki O, Yu J.J Mater Chem A, 2014, 2: 17828

[14] Tosheva L, Valtchev V P. Chem Mater, 2005, 17: 2494

[15] Gonthier S, Thompson R W. Stud Surf Sci Catal, 1994, 85: 43

[16] Deng X J, Wang Y N, Shen L, Wu H H, Liu Y M, He M Y. Ind Eng Chem Res, 2013, 52: 1190

[17] Xia Q H, Gao Z. Mater Chem Phys, 1997, 47: 225

[18] Zhang H J, Liu Y M, Jiao Z, He M Y, Wu P. Ind Eng Chem Res, 2009, 48: 4334

[19] Zuo Y, Wang X S, Guo X W. Ind Eng Chem Res, 2011, 50: 8485

[20] Chen L, Wang Y M, He M Y. Mater Res Bull, 2011, 46: 698

[21] Huang D G, Zhang X, Liu T W, Huang C, Chen B H, Luo C W, Ruckenstein E, Chao Z S. Ind Eng Chem Res, 2013, 52: 3762

[22] Wang M, Zhou J C, Mao G Y, Zheng X L. Ind Eng Chem Res, 2012, 51 : 12730

[23] Zhang J H, Yue M B, Wang X N, Qin D. Microporous Mesoporous Mater, 2015, 217: 96

[24] Ren N, Yang Z J, Lü X C, Shi J, Zhang Y H, Tang Y. Microporous Mesoporous Mater, 2010, 131: 103

[25] Ren N, Bronić J, Subotić B, Lü X C, Yang Z J, Tang Y. Microporous Mesoporous Mater, 2011, 139: 197

[26] Ren N, Bronić J, Subotić B, Song Y M, Lü X C, Tang Y. Microporous Mesoporous Mater, 2012, 147: 229

[27] Xue T, Wang Y M, He M Y. Microporous Mesoporous Mater, 2012, 156: 29

[28] Xue T, Chen L, Wang Y M, He M Y. Microporous Mesoporous Mater, 2012, 156: 97

[29] Xue T, Wang Y M, He M Y. Solid State Sci, 2012, 14: 409

[30] Majano G, Darwiche A, Mintova S, Valtchev V. Ind Eng Chem Res, 2009, 48: 7084

[31] Li G, Wang X S, Guo X W, Liu S, Zhao Q, Bao X H, Lin L W. Mater Chem Phys, 2001, 71: 195

[32] Klaas J, Kulawik K, Schulz-Ekloff G, Jaeger N I. Stud Surf Sci Catal, 1994, 84: 2261

[33] Bertucci C, Lazzaroni R, Salvadori P, Johnson W C Jr. J Chem Soc, Chem Commun, 1981: 590 


\title{
Graphical Abstract
}

Chin. J. Catal., 2015, 36: 1928-1935 doi: 10.1016/S1872-2067(15)60955-X

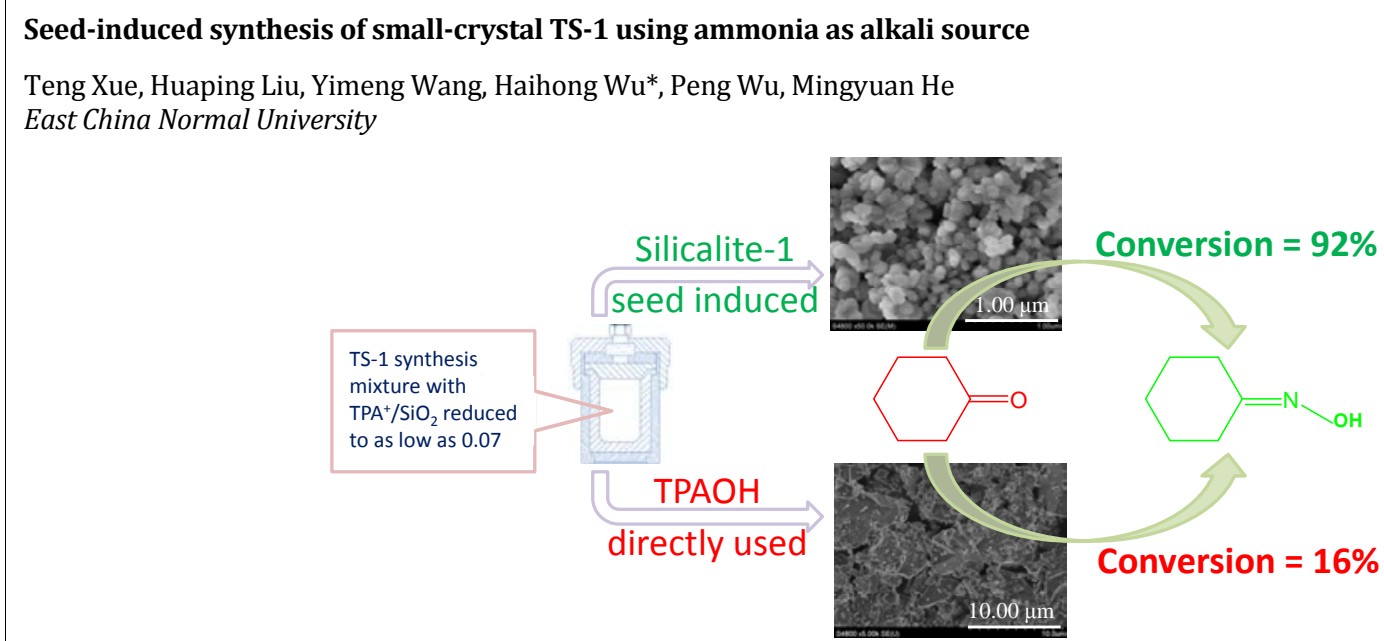

Small-sized TS-1 was synthesized through seed-induced approach with the $\mathrm{TPA}^{+} / \mathrm{SiO}_{2}$ reduced to as low as 0.07 . The small-sized TS-1 showed enhanced performance when catalyzing cyclohexanone ammoximation compared with the bulk TS-1 prepared directly using TPAOH.

[34] Jacobs P A, Beyer H K, Valyon J. Zeolites, 1981, 1: 161

[35] Jansen J C, van der Gaag F J, van Bekkum H. Zeolites, 1984, 4: 369

[36] Scarano D, Zecchina A, Bordiga S, Geobaldo F, Spoto G, Petrini G, Leofanti G, Padovan M, Tozzola G. J Chem Soc, Faraday Trans, 1993, 89: 4123

[37] Shibata M, Gérard J, Gabelica Z. Stud Surf Sci Catal, 1997, 105: 245

[38] Zhao Q, Han X W, Liu X M, Zhai R S, Lin L W, Bao X H, Guo X W, Li G,
Wang X S. Acta Phys-Chim Sin (赵琦, 韩秀文, 刘秀梅, 翟润生, 林 励吾, 包信和, 郭新闻, 李钢, 王祥生. 物理化学学报), 1998, 14: 906

[39] van der Pol A J H P, van Hooff J H C. Appl Catal A, 1992, $92: 93$

[40] Vayssilov G N. Catal Rev Sci Eng, 1997, 39: 209

[41] Sazama P, Dedecek J, Gabova V, Wichterlova B, Spoto G, Bordiga S. J Catal, 2008, 254: 180

\section{以氨水做碱源胶态晶种导向法合成小晶粒TS-1分子篮}

\author{
薛 腾, 刘华萍, 王一萌, 吴海虹 ${ }^{*}$, 吴鹏, 何鸣元 \\ 华东师范大学化学与分子工程学院, 上海市绿色化学与化工过程绿色化重点实验室, 上海200062
}

摘要: TS-1分子笁具有MFI拓扑结构, 因其独特的择形选择性和优异的催化氧化能力而广受关注. 最早报道的TS-1合成方法采用 大量四丙基氢氧化铵(TPAOH)作为有机结构导向剂, TPAOH价格昂贵, 制约着TS-1分子篮大规模应用. 开发廉价、环境友好的合 成工艺是TS-1分子篮合成领域的重要课题. 以价格相对较低的四丙基溴化铵(TPABr)代替TPAOH做有机结构导向剂, 以氨水为 碱源可合成TS-1分子篮, 但产物晶粒尺寸远远大于以TPAOH做模板的合成结果, 影响TS-1分子篮的传质和催化性能. 因此, 人们 对该法进行了改进, 选用有机胺作为碱源, TPABr 为结构导向剂合成TS-1分子篮, 但始终未能将其晶粒尺寸降至 $1 \mu \mathrm{m}$ 以下. 在合 成体系中引入预先合成的TS-1分子篎或TS-1胶态前驱体作为晶种可以促进成核, 缩短成核诱导期, 有利于获得小晶粒尺寸的TS-1 分子篮. 此类方法往往需要辅助以大量有机胺等结构导向剂; 胶态TS-1前驱体的制备需要特别小心以保证晶种中Ti的四配位状 态, 通常需要经历低温水解钣酸四丁酯(TBOT)和高温加热除醇等繁琐步骤. 而胶态纯硅silicalite-1制备则相对简单, 且已广泛用 于导向合成同样具有MFI结构的ZSM-5沸石, 但目前鲜有以silicalite-1做晶种合成TS-1分子篎的报道. 基于此, 本文以纯硅胶态 silicalite-1为晶种, 以氨水做碱源, 辅助以少量TPABr做导向剂, 合成了小晶粒TS-1分子篎, 并以正已烯环氧化和环己酮氨肟化做探 针反应考察了所得TS-1分子篮的催化氧化性能.

$\mathrm{X}$ 射线衍射结果表明, 当晶种中 $\mathrm{SiO}_{2}$ 占合成体系中 $\mathrm{SiO}_{2}$ 的 $10 \mathrm{wt} \%$ (晶种引入 $\mathrm{TPAOH}, \mathrm{TPAOH} / \mathrm{SiO}_{2}=0.35$ ), 加入 $\mathrm{TPABr}$ $\left(\mathrm{TPABr} / \mathrm{SiO}_{2}=0.03\right)$ 做辅助结构导向剂, 即合成体系中总 $(\mathrm{TPAOH}+\mathrm{TPABr}) / \mathrm{SiO}_{2}$ 摩尔比低至0.07时, 所得样品依然具有良好的结晶 度. 扫描电镜照片观察不到无定形物存在; 晶种中 $\mathrm{SiO}_{2}$ 占合成体系中 $\mathrm{SiO}_{2}$ 的 $10 \mathrm{wt} \%$ 时, 所得TS- 1 晶粒尺寸约为 $250 \mathrm{~nm} \times 150 \mathrm{~nm} \times$ $50 \mathrm{~nm}$; 其他条件不变, 胶态晶种用量增加到 $15 \mathrm{wt}$ \% 时, 初级晶粒尺寸基本保持不变, 晶粒-晶粒之间交叉生长, 形成孪生形貌; 继 续增加胶态晶种用量至 $20 \mathrm{wt} \%$ 时, 晶粒尺寸下降至仅 $100 \mathrm{~nm}$ 左右; 而用 $20 \mathrm{wt} \%$ 胶态晶种所含相同量的TPAOH来代替胶态晶种, 得到样品呈近 $10 \mu \mathrm{m}$ 的大块状. 与之对应的是, 胶态silicalite-1晶种导向得到的小晶粒TS-1分子篮具有比直接用TPAOH得到的大 块状样品更大的外比表面积和堆积孔体积. 分析结果显示所得TS-1分子篮的体相 $\mathrm{TiO}_{2} / \mathrm{SiO}_{2}$ 比在41-43. 红外光谱和紫外可见光谱 
结果表明, 胶态晶种导向法所得TS-1分子篎中的 Ti主要以四配位状态存在, 而直接用TPAOH合成的大块状样品则呈现显著骨架 外Ti吸收峰, 说明胶态晶种有助于Ti物种进入分子篮骨架.

在催化正己烯环氧化反应时, 用胶态silicalite-1晶种导向得到的小晶粒TS-1分子篎表现出与大块状TS-1相似的催化性能; 而 以环己酩氨肜化做探针反应时, 小晶粒TS-1分子笁因具有外比表面积大和扩散路径短等优点而表现出远远高于大块状TS-1分子 篮的催化活性. 但与文献报道的相同 $\mathrm{SiO}_{2} / \mathrm{TiO}_{2}$ 比的 $\mathrm{TS}-1$ 分子篮比较, 本文所得小晶粒 $\mathrm{TS}-1$ 分子篮催化正己烯环氧化的活性略差. 提高该小晶粒TS-1分子笁正已烯环氧化活性和建立构-效关系是下一步工作的重点.

关键词: 小晶粒; TS-1分子篎; 晶种导向合成; 氨水; 催化氧化; 环己酮氨肜化

收稿日期: 2015-06-09. 接受日期: 2015-07-14. 出版日期: 2015-11-20.

*通讯联系人. 电话/传真: (021)62238510; 电子信箱: hhwu@chem.ecnu.edu.cn

基金来源：国家自然科学基金(21403070，21373088); 上海市教育委员会科研创新项目(13zz038); 上海市科委“创新行动计划” 基 础研究重点项目(12JC1403600); 国家科技支撑计划(2012BAE05B02); 上海市重点学科项目(B409).

本文的英文电子版由Elsevier出版社在ScienceDirect上出版(http://www.sciencedirect.com/science/journal/18722067). 